\title{
Impacts of Dynamic Marketing Capabilities on Performance in Exporting
}

\author{
Yung-Chul Kwon \\ Yeoungnam University, Daegu, South Korea \\ Email: yckwon@ynu.ac.kr
}

How to cite this paper: Kwon, Y.-C. (2021). Impacts of Dynamic Marketing Capabilities on Performance in Exporting. Open Journal of Business and Management, 9, 2119 2135.

https://doi.org/10.4236/ojbm.2021.95112

Received: June 21, 2021

Accepted: August 14, 2021

Published: August 17, 2021

Copyright (c) 2021 by author(s) and Scientific Research Publishing Inc. This work is licensed under the Creative Commons Attribution International License (CC BY 4.0).

http://creativecommons.org/licenses/by/4.0/

\begin{abstract}
The purpose of this paper is to construct the operationalization of dynamic marketing capabilities and analyze its effectiveness in overseas market. The author examines the impacts of dynamic marketing capabilities on performance based upon the sample of 180 export companies in Korea. The findings reveal that dynamic marketing capabilities such as "market responding capabilities" and "marketing resource rebuilding capabilities" have significant impacts on performance in exporting. The result verifies the effectiveness of dynamic marketing capabilities in performance. It is necessary for firms to build dynamic marketing capabilities to achieve the desired performance, especially in the overseas market, where the market environment is completely different. Even though this study attempts to shed new light on theory of dynamic capabilities from a marketing perspective, there is a need for continuous discussions and research around the conceptualization and operationalization of dynamic marketing capabilities.
\end{abstract}

\section{Keywords}

Dynamic Marketing Capabilities, Performance, Exporting

\section{Introduction}

Profits vary significantly among different companies even in the same industry. There is a leader in the group as well as a low-ranking follower. In the past, researchers tried to approach this gap in profitability in terms of industrial organization structure (Porter, 1980). However, there are limitations to merely explain the huge gap in profitability among companies in the same competitive structure. Thus, studies began to focus on internal resource issues among companies to examine the profitability gap, rather than on industrial organization structure. Among them, the resource-based view received great attention. This view argued 
that profitability among companies even in the same industry varies according to the characteristics of the company resources owned, that is, how valuable and rare they are, and how difficult they are to be imitated by competitors (Barney, 1991; Grant, 1991; Collis \& Montgomery, 1995). However, it has been pointed out that the resource-based view also has limitations in its ability to guarantee a company's profitability in rapidly changing competitive environment. In other words, companies can succumb to resource rigidity, which makes them so tied to their own unique resources that they fail to adjust to rapid environmental changes, thereby, falling behind the competition. If a company's core resources or capabilities become unsuitable for a rapid changed environment, for instance, "core competence" may turn into "core rigidity" (Leonard-Barton, 1995). It is actually unusual to find a turnaround in the status of a leading company in related industries, but if the leading company falls into resource rigidity, the competitive position does change occasionally. A good example could be the case that Apple and Samsung Electronics overtook Nokia and Motorola in the smartphone market. Nokia and Motorola had once been in the lead positions in the cellular phone market, but they placed too much confidence in their core competences and fell behind Apple and Samsung Electronics in the market shift to smartphones.

Phenomena such as the reduction of product life cycle, followed by changes in technology and consumer taste, globalization of competition, and the rapid spread of information through the Internet, further increase environmental uncertainty, thereby quickly changing the value of core resources and competences that had previously formed the foundation for competitive advantages. Thus, in order for companies to make continuous profits in a radically changed environment and maintain their competitive edge, they must stay one step ahead of the competition by recognizing and responding to environmental changes. Additionally, to guarantee this sustainable competitive position, they should be supported by a new set of resources and competences.

Recently, the timely response to environmental changes and the securing of a competitive advantage through the capability to renew and rebuild resources have been explained by the concept of dynamic capabilities (Teece et al., 1997; Helfat, 1997; Eisenhardt \& Martin, 2000). In the meanwhile, Zahra et al. (2006) argue that this kind of dynamic capabilities is required in all value chain functions such as R\&D, manufacturing, marketing, and finance. For instance, Deeds et al. (2000) regarded the capability to develop new products as a dynamic capability. It was also pointed out there is a problem in considering the entire resources or competences as contributing to business performance of a company, since different resources or competences are required for different value chain functions. Therefore, it is necessary to focus on the impacts of specific resources or competences on the effectiveness of related value chain functions to empirically verify the resource-based view (Ray et al., 2004).

In this context, there is an urgent need for dynamic capabilities in marketing 
in today's rapidly changing market environment. Consequently, this study aims to reestablish the concept of dynamic capabilities from a marketing perspective, and empirically analyze the impacts of dynamic marketing capabilities on performance. Studies on the effectiveness of marketing capabilities have been relatively frequent (Hooley et al., 1999; Moore \& Fairhurst, 2003; Morgan et al., 2009; Vorhies \& Morgan, 2005; Vorhies et al., 2009). However, with some exceptions (Griffith et al., 2006; Bruni \& Verona, 2009), few approached marketing capabilities from the dynamic perspective. In particular, this study assumes that dynamic marketing capabilities are required more in overseas markets, where the business environment is completely different, and thus aims to analyze the effectiveness of dynamic marketing capabilities in export companies. This study has academic and practical significance in that it applies the concept of dynamic capabilities to marketing, and analyzing its effectiveness in overseas markets.

\section{Concept and Components of Dynamic Marketing Capabilities}

Teece et al. (1997) conducted a leading study that systematically established the concept of dynamic capabilities; they defined dynamic capability as "the ability to integrate, build, and reconfigure internal and external competences to address rapidly changing environments." In the same vein, Helfat (1997) considered dynamic capabilities as the "alteration of their resources or knowledge in response to rapid environment changes". Meanwhile, Eisenhardt \& Martin (2000) emphasized the strategic routine in which companies reconfigure resources as markets form, change, and become extinct. All these studies regarding dynamic capabilities emphasize the timely response to market changes as well as the renewal and rebuilding of resources. This consideration is in line with the concept of "dynamic resource management" by Wernerfelt (1984), who emphasized "the optimal resource portfolio as a balance between exploitation of existing resources and development of new ones to maintain competitive advantages," and the concept of "resource fit" by Hiroyuki (1987), who emphasized the importance of resource management fit for future strategies.

For the empirical verification there have been some studies that specifically analyze the components of dynamic capabilities. For instance, Teece (2007, 2018) categorized the components of dynamic capabilities into three subsets such as 1) ability to sense and shape opportunities and threats, 2) ability to seize opportunities, and 3) ability to expand, integrate, protect, and reconfigure tangible and intangible resources. To analyze the impacts of these capabilities on the performance of high-tech ventures, Kwon (2013) also classified the components of dynamic capabilities into subsets such as 1) environment sensing capability, that can sense market changes, 2) innovative responding capability, that can respond to market changes, and 3) resource renewing capability, that can rebuild resources.

According to Day (1994), marketing capabilities can be composed of two 
types of capabilities at least. One is related to outside-in capabilities that accurately predict diverse changes in external markets, such as market sensing and technology monitoring as well as changes in customers' needs while the other is related to inside-out capabilities that focus on managing in-house company resources such as technological and financial resources, costs, and human resources. Based on the types of marketing capabilities stated by Day (1994), therefore, dynamic marketing capabilities can be subdivided into two components such as 1) ability to respond to market changes, namely, "market responding capabilities", and 2) ability to integrate, build, and reconfigure marketing resources, namely, "marketing resource rebuilding capabilities". In this sense, the market responding capabilities correspond to outside-in marketing capabilities, while the marketing resource rebuilding capabilities correspond to inside-out marketing capabilities.

As a key component of dynamic marketing capabilities, in the meanwhile, some studies focused only on the market responding capabilities (Griffith et al., 2006) while other studies focused only on the marketing resource rebuilding capabilities regarding the creation, use, and integration of marketing knowledge and resources (Bruni \& Verona, 2009). To completely support the concept of dynamic marketing capabilities, however, these must include capabilities to respond to market changes as well as capabilities to renew or rebuild marketing resources.

\section{Research Model and Hypotheses}

In analyzing the effectiveness of dynamic marketing capabilities, this study aims to establish a research model as shown in Figure 1, with two types of dynamic marketing capabilities, namely "market responding capabilities" and "marketing resource rebuilding capabilities". Assuming that dynamic marketing capabilities are required more in overseas markets, where market environments are completely different, this study targets export companies as the sample of the research. Considering the fact that export performance may vary according to firm size and export experience (Andersson et al., 2004; Bortoluzzi et al., 2014; Carlsson

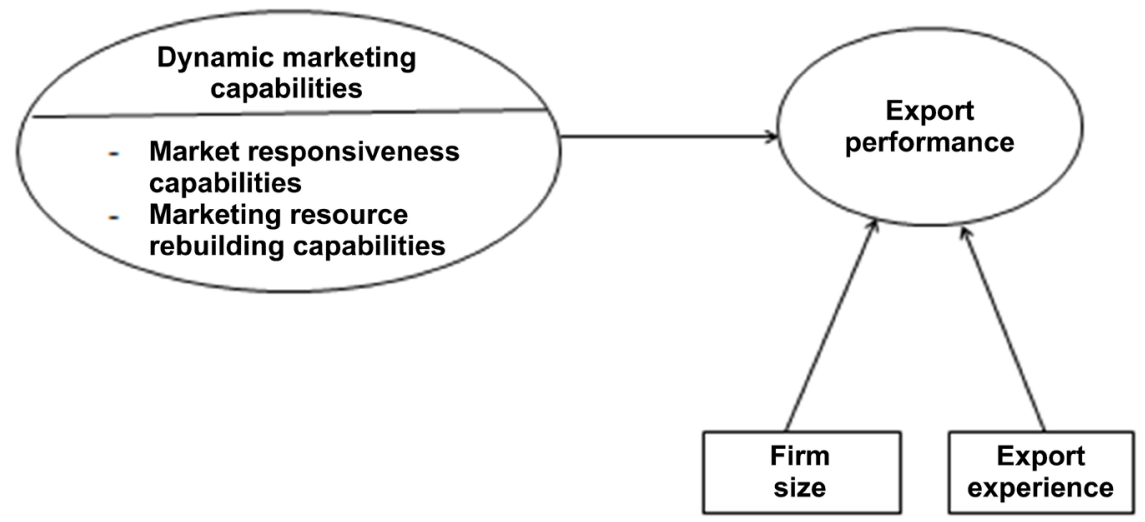

Figure 1. Research model for the effectiveness of dynamic marketing capabilities. 
et al., 2005; Reid, 1982; Samiee \& Walters, 1990), these are adopted as control variables to analyze the influences of dynamic marketing capabilities on export performance in this analysis.

Companies' market responding capabilities to environmental changes have been perceived as a crucial element of dynamic capabilities. For instance, Teece et al. (1997) emphasized the importance of timely adjustment to environmental change. As a key function of dynamic capabilities, in the same vein, Eisenhardt \& Martin (2000) considered dynamic capabilities as matching market change and even creating a new market.

The concept of market responding capabilities is also in line with the concept of market orientation, where information is captured on market changes to enhance a company's competitive advantage and timely market response, by sharing it among interfunctional departments (Kohli \& Jaworski, 1990). Narver \& Slater (1990) specifically emphasized information about consumers and competitors, and argued that this type of market orientation contributes to the improvement of competitive advantage by enabling companies to take timely measures, as they increase consumer satisfaction, while also better captivating the strengths and weaknesses of competitors. Empirical studies verified that this market-responsive market orientation has positive impacts on the successful introduction of new products and business performance (Narver \& Slater, 1990; Jaworski \& Kohli, 1993; Pelham, 2000; Hong \& Chen, 1998; Homburg \& Pflesser, 2000). The concept of market responsiveness is also in line with the concept of marketing innovation that references the innovative marketing activities based on market environmental changes. It has been acknowledged that innovation in market knowledge, product development, product delivery, and customer management contributes to enhance firm's competitive advantages (Hong \& Chaiy, 2008; Abosag \& Brennan, 2017).

The direct effectiveness of market responsiveness has been proven by empirical verification. For example, Griffith et al. (2006) defined dynamic capabilities as market responsiveness-the ability to respond more promptly to existing and new demands of consumers-and conducted an empirical analysis of American retailers. As a result, they clarified that higher retail market responsiveness led to higher marketing performance. In the same vein, Fang \& Zou (2009) who defined dynamic market responsiveness as the ability to efficiently and promptly respond to product development, supplier management, and customer relationship management issues in accordance with market environment changes analyzed its effectiveness on the operation of international joint ventures in China. As a result, they proved that such market responsive capabilities have positive impacts on the business performance of these joint ventures.

This kind of market responding capabilities should play more important roles in overseas markets of which business environments are completely different from those of domestic market. That is why it has been also proven that the market-responsive market orientation had positive impacts on the export mar- 
keting performance (Cadogan et al., 2002; He et al., 2018; Kwon \& Hu, 2000; Rose \& Shoham, 2002).

H1: Market responding capabilities of export companies will have positive impacts on export performance.

According to the resource-based view, companies that have valuable and scarce resources, can achieve superior competitive advantages compared to those that do not have (Barney, 1991). However, the weakness of the resource-based view is that the value of those resources may be out of date due to environmental changes. A good example could be the fall of Nokia and Motorola. These companies were so focused on their existing technology in the cellular phone market that they fell behind Samsung Electronics and Apple in developing new smartphone technology. This example implies that it should be necessary to attain "resource fit" by continuously renewing resources according to changes in the technological environment as well as in customer needs in order to maintain competitive advantages (Hiroyuki, 1987).

Dynamic capabilities underscored the importance of resource fit along with market responsiveness, following environmental changes. For example, Teece et al. (1997) emphasized the ability to adapt, integrate, and reconfigure internal and external organizational skills, resources, and functional competences to address rapidly changing environments as an important function of dynamic capabilities. This is in line with the concept of the optimum resources portfolios through “dynamic resource management" by Wernerfelt (1984), who argues that to make a competitive advantage sustainable, it is important to balance the use of existing resources with the development of new ones. McGrath (2001) also stressed the importance of balancing existing resources with new ones, explaining the importance of efforts to develop new resources or knowledge with a change seeking learning process for adequately coping with a rapidly changing environment.

Meanwhile, from a marketing perspective, Johnson et al. (2003) emphasized the importance of market-focused strategic flexibility, in which companies clarify, obtain, and configure marketing resources (brands, vendors, clients, dealer loyalty, customer trust, marketing experts, etc.) and reconfigure strategic options, particularly with regard to products and markets, to achieve sustainable competitive advantage. In general, marketing resources have the character of intangible resources. For instance, Srivastava et al. (2001) categorized marketing resources into relational and intellectual marketing resources. While the former refers to amicable relations with clients, distributors, and suppliers based on mutual trust and reputation, the latter refers to knowledge about the market. Both are intangible and can't be easily imitated by competitors. In the resource-based view, existing intangible marketing resources contribute to competitive advantage; however, if resources are not renewed in accordance with changes in market environments, as from the dynamic capabilities perspective, competitive advantage may in fact be damaged due to resource rigidity. 
Empirical studies also prove that the abilities to rebuild resources, by integrating, adding, and reconfiguring resources as dynamic capabilities, are major drivers of competitive advantage and business performance. For example, $\mathrm{Wu}$ (2010) defined dynamic capabilities as the ability to integrate, learn, and reconfigure resources, empirically analyzing 253 companies in the high technology industry in Taiwan. Consequently, it was proven that this resource rebuilding of dynamic capabilities has positive impacts on competitive advantage. From an analysis of multinational corporations operating in Korea, it was found that the ability to gain and renew intellectual resources such as technology, knowledge, know-how, and skills has positive impacts on the business performance of local subsidiaries (Kwon, 2010). Furthermore, it was also proven that the firms possess dynamic marketing capability of creating, using and integrating marketing resources do have more advantages in the creation of new products and the changes in the new product development than those who don't have (Bruni \& Verona, 2009).

This study defined the abilities to gain, integrate, and reconfigure new marketing resources according to change in export environments as "marketing resource rebuilding capabilities", and formulated the following hypothesis.

$\mathrm{H} 2$ : Marketing resource rebuilding capabilities of export companies will have positive impacts on export performance.

\section{Research Method}

\subsection{Surveyed Companies}

To verify the effectiveness of dynamic marketing capabilities of export companies, this study requested from the Korea International Trade Association (KITA) a list of export companies in the manufacturing industry in the Daegu and Gyeongbuk regions, the southern part of Korea. The list included 479 such companies. Data was collected from the CEOs or overseas department managers of these companies during one month, October 2017. The final collection of the questionnaires resulted in a response rate of $39.9 \%$, equaling 191 company responses. Among them, 180 companies were selected for final analysis, excluding 11 companies with poor responses.

To reduce the problem caused by the common method variance (CMV), the following ex ante method was used. First, the respondents were convinced that the identities of the respondents would be anonymous and the responses would be used only for research purposes. This encouraged the respondents to answer as honestly as possible. Second, the order of variables in the questionnaire was randomly arranged, reducing the possibility that the respondents answered by subjectively predicting the relationship among variables (Chang et al., 2010). Since the problem of CMV can't be perfectly solved with the ex ante method, Harman's single factor test was conducted as a posteriori test. As a result of inputting 16 variables, used in the analysis, and conducting an unrotated factor analysis, four factors with explanatory power (eigenvalue $>1.000$ ) were ex- 
tracted. The factor with the biggest explanatory power accounted for $22.32 \%$ of all variances, while the other three factors accounted for $50.17 \%$, proving that there was no single general factor that caused the problem of CMV (Harman, 1967; Podsakoff \& Organ, 1986).

\subsection{Operant Definition and Measurement of Variables}

First, export performance as a dependent variable was measured in terms of competitive performance and financial performance based on previous studies that classified business performance into two categories: a competition-related index and a finance-related index (Diamantopoulos et al., 2014; Fang \& Zou, 2009; Griffith \& Zhao, 2015; Lisboa et al., 2013; Oliveira et al., 2012; Zhan \& Luo, 2008). Competitive performance, which represents the enhancement of competitive advantage in export markets, is measured in four items: 1) improvement of brand awareness (EC1), 2) improvement of price competitiveness (EC2), 3) improvement of quality competitiveness (EC3), and 4) improvement of relationships with clients (EC4). Financial performance is also measured in four items: 1) total sales revenues (EM1), 2) total sales profits (EM2), 3) return on investment (EM3), and 4) margin (EM4) in exporting. We have measured export performance in terms of subjective perception since objective financial measures do not control for variations caused by external factors such as foreign exchange rates (Andersson et al., 2001; Lisboa et al., 2013). Here, we employed three-year average estimates to minimize the influence of short-term performance variations. Thus, these were all assessed based on a 7-point Likert scale ( $1=$ extremely dissatisfied; 7 = extremely satisfied) to determine how satisfied the respondents were with the relevant achievements compared with major competitors over the last three years.

The operant definition of market responding capability, which is a key element of dynamic marketing capabilities, is the ability to respond to various changes in export markets in timely manner. This is in line with the outside-in capabilities of a company that copes with market changes as stated by Day (1994). In consequence, this study measured market responding capabilities based on a 7 -point Likert scale ( $1=$ extremely low; $7=$ extremely high), using the following four items: 1) promptly coming up to new demands of clients (RS1), 2) constantly improving product performance (RS2), 3) constantly introducing new marketing strategies or programs (RS3), and 4) promptly responding to the strategic changes of competitors (RS4). These items were developed based on the previous studies by Day (1994), Fang \& Zou (2009), and Griffith et al. (2006).

The operant definition of marketing resource rebuilding capability, another key element of dynamic marketing capabilities, is the ability to integrate, form, and reconfigure marketing resources internally according to changes in export environments. This is in line with the outside-in capabilities of a company that copes with market changes as stated by Day (1994). Therefore, this study measured marketing resource rebuilding capabilities based on a 7-point Likert scale 
( 1 = extremely low; 7 = extremely high), using the following four items: 1$)$ constantly monitoring the state (sufficient/insufficient) of marketing resources (patents, brands, and market data, marketing experts, tools and systems, trust with clients, etc.) (RM1), 2) constantly supplementing necessary marketing resources (RM2), 3) procuring marketing resources from the outside (clients, distributors, agents, etc.) if necessary (RM3), and 4) maximizing utility of marketing resources through adjustments and reconfiguration (RM4). These items were developed based on the previous studies by Day (1994), Johnson et al. (2003), and Srivastava et al. (2001).

At the same time, export performance may vary according to firm size and export experience (Andersson et al., 2004; Bortoluzzi et al., 2014; Carlsson et al., 2005; Reid, 1982; Samiee \& Walters, 1990). Therefore, for control variables to check the influences of firm size and export experience in export performance, this study measured firm size by the number of employees, and export experience by years of business since the company began exporting.

\subsection{Reliability and Validity Analysis of Constructs}

Exploratory factor analysis was conducted to verify the validity of the measurement variables. For factor rotation, the VARIMAX, in the orthogonal rotation method, was adopted in order to maintain independence among factors. As a result, the constructs measured by this study are accurately classified, and the factor loading of variables shows a satisfactory level at 0.6 and above. The reliability that represents the internal consistency of variables is considered favorable if the Cronbach Alpha is above 0.7 (Nunnally, 1978). As a result of the reliability testing, most variables have the Cronbach Alpha of 0.7 and above, indicating that there is no significant problem in the internal consistency of variables. In addition, confirmative factor analysis (CFA) was conducted in order to analyze the convergent validity of measurement items as well as the concepts of exogenous and endogenous variables for the items that went through the exploratory analysis. As can be seen in Table 1, the factor loading was 0.5 and higher in all exogenous and endogenous variables, and the $t$-value was 2.00 and above. Generally, convergent validity is considered acceptable if the loading of measurement items is higher than 0.5 and the $\mathrm{t}$-value is 2.0 and above (Steenkamp \& Van Trijp, 1991). Therefore, convergent validity could be confirmed as the value exceeded the standard level in all items. Moreover, as a result of measuring composite reliability (CR) and average variance extracted (AVE), it was found that both CR and AVE exceed the standard levels of 0.70 and 0.50 , respectively, in all measurement items excluding marketing resource rebuilding capabilities. This showed that the survey questions are valid to a certain degree (Fornell \& Larcker, 1981).

\section{Results of Hypothesis Testing}

To prove Hypotheses 1 and 2, this study conducted a structure equation analysis, 
Table 1. Result of confirmative factor analysis.

\begin{tabular}{|c|c|c|c|c|c|c|}
\hline \multicolumn{7}{|c|}{ Endogenous and exogenous variables } \\
\hline Factor & Variable & $\begin{array}{l}\text { Standardization } \\
\text { factor loading }\end{array}$ & t value & $p$ value & $\begin{array}{l}\text { Composite } \\
\text { reliability }(\mathrm{CR})\end{array}$ & $\begin{array}{l}\text { Average variance } \\
\text { ) extracted (AVE) }\end{array}$ \\
\hline \multirow{4}{*}{$\begin{array}{c}\text { Market } \\
\text { responsiveness } \\
\text { capabilities }\end{array}$} & RS1 & 0.824 & - & - & \multirow{4}{*}{0.79} & \multirow{4}{*}{0.64} \\
\hline & RS2 & 0.837 & 12.378 & 0.000 & & \\
\hline & RS3 & 0.878 & 10.297 & 0.000 & & \\
\hline & RS4 & 0.842 & 11.675 & 0.000 & & \\
\hline \multirow{4}{*}{$\begin{array}{l}\text { Marketing } \\
\text { resource } \\
\text { rebuilding } \\
\text { capabilities }\end{array}$} & RM1 & 0.860 & - & - & \multirow{4}{*}{0.76} & \multirow{4}{*}{0.44} \\
\hline & RM2 & 0.908 & 14.850 & 0.000 & & \\
\hline & RM3 & 0.484 & 5.971 & 0.000 & & \\
\hline & RM4 & 0.801 & 12.127 & 0.000 & & \\
\hline \multirow{4}{*}{$\begin{array}{l}\text { Competitive } \\
\text { performance }\end{array}$} & $\mathrm{EC} 1$ & 0.830 & - & - & \multirow{4}{*}{0.83} & \multirow{4}{*}{0.55} \\
\hline & EC2 & 0.735 & 10.740 & 0.000 & & \\
\hline & EC3 & 0.899 & 13.900 & 0.000 & & \\
\hline & EC4 & 0.886 & 13.502 & 0.000 & & \\
\hline \multirow{4}{*}{$\begin{array}{c}\text { Financial } \\
\text { performance }\end{array}$} & EM1 & 0.876 & - & - & \multirow{4}{*}{0.84} & \multirow{4}{*}{0.57} \\
\hline & EM2 & 0.743 & 10.374 & 0.000 & & \\
\hline & EM3 & 0.786 & 11.838 & 0.000 & & \\
\hline & EM4 & 0.741 & 10.070 & 0.000 & & \\
\hline
\end{tabular}

$x^{2} / \mathrm{df}=1.418\left(x^{2}=113.275, \mathrm{df}=95\right), \mathrm{GFI}=0.903, \mathrm{AGFI}=0.865, \mathrm{CFI}=0.822, \mathrm{RMSEA}=0.048$.

with market responding capabilities and marketing resource rebuilding capabilities as exogenous variables, and export performance as an endogenous variable. In this process, export performance was analyzed separately by dividing it into competitive performance and financial performance. Figure 2 is the verification result of competitive performance, and Figure 3 is the verification result of financial performance. The goodness of fit of the research model revealed the following: $x^{2}(74)=198.347(p=0.01)$, GFI $=0.865$, AGFI $=0.808, \mathrm{CFI}=0.900$, RMSEA $=0.097$ in competitive performance; and $x^{2}(74)=182.38(p=0.01)$, GFI $=0.877, \mathrm{AGFI}=0.826, \mathrm{CFI}=0.919, \mathrm{RMSEA}=0.090$ in financial performance. This indicated that even though the goodness of fit of the path modeling is not outstanding, there is no problem in using this model in analysis since GFI and CFI are close to, or higher than, 0.90 , the generally allowed level of analysis.

As a result of analyzing Hypothesis 1, the causation between market responding capabilities and export performance is as follows. The path coefficients $(\beta)$ of competitive performance in Figure 2 and financial performance in Figure 3 turned out to be 0.288 and 0.081 , respectively. This showed that competitive performance was statistically significant $(p<0.01)$ but financial performance was not, thereby the result partially supports Hypothesis 1 . This result implies that while market responding capabilities contribute to enhancing competitive 


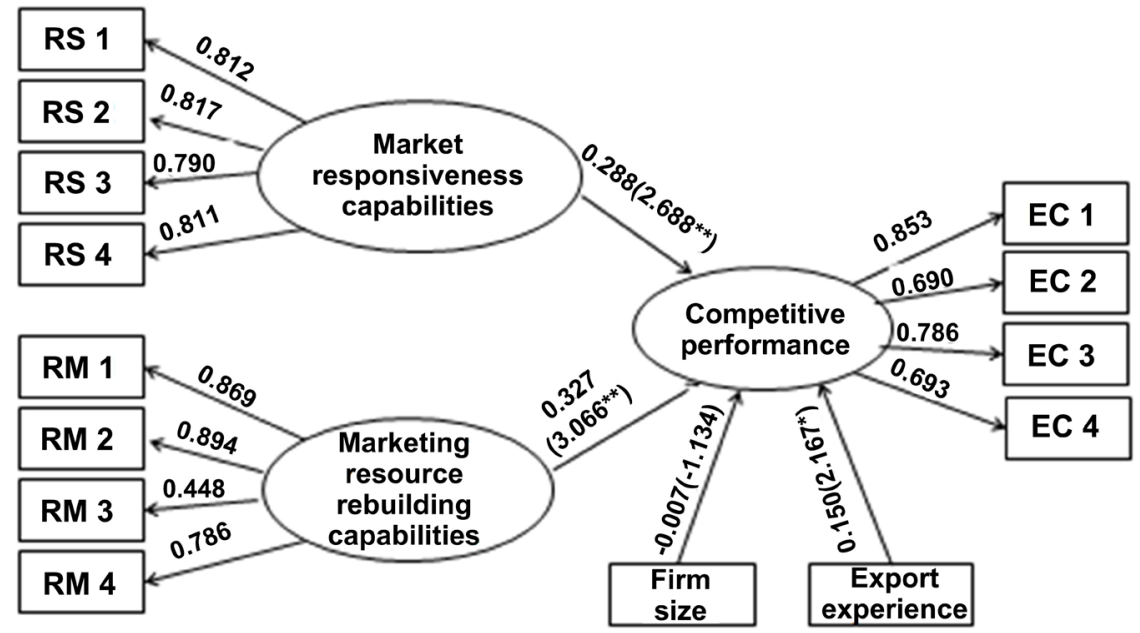

$x^{2} / d f=2.680\left(x^{2}=198.347, d f=74\right), G F I=0.865$

$\mathrm{AGFI}=0.808, \mathrm{CFI}=0.909$, RMSEA $=0.097$

${ }^{*} p<0.05 ;{ }^{* *} p<0.01$

Figure 2. Verification result of $\mathrm{H} 1$ and $\mathrm{H} 2$ (competitive performance).

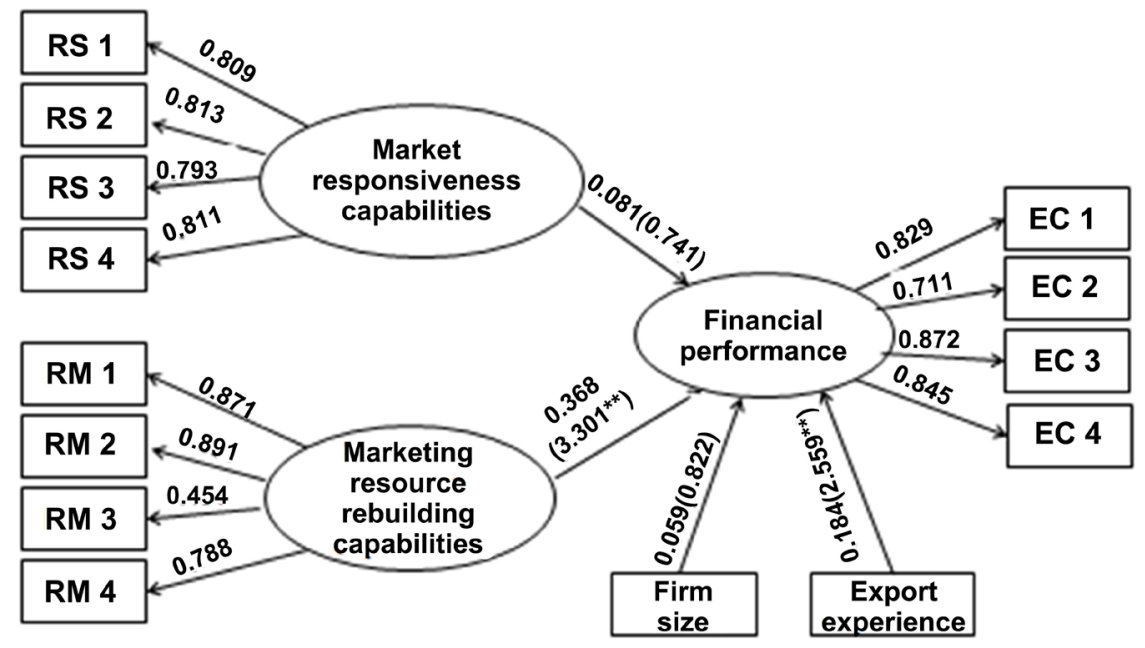

$x^{2} / d f=2.680\left(x^{2}=198.347, d f=74\right), G F I=0.865$

AGFI $=0.808, \mathrm{CFI}=0.900, \mathrm{RMSEA}=0.097$

${ }^{*} p<0.05 ;{ }^{* *} p<0.01$

Figure 3. Verification result of $\mathrm{H} 1$ and $\mathrm{H} 2$ (financial performance).

performance, there are limitations with this leading to financial performance. These findings are not consistent with the results of a study conducted by Griffith et al. (2006) verifying the positive impact of market responsiveness capabilities on financial performance of small retailers in the U.S. market.

On the other hand, the causation between marketing resource rebuilding capabilities and export performance was different as follows. The path coefficients ( $\beta$ ) of competitive performance and financial performance turned out to be $0.327(p<0.01)$ and $0.368(p<0.01)$, respectively, indicating that both were sta- 
tistically significant. This result supports Hypothesis 2, which assumes that marketing resource rebuilding capabilities have positive impacts on export performance. These findings are consistent with the results of a study conducted by $\mathrm{Wu}$ (2010) analyzing marketing resource manipulation capabilities of 253 companies in the high technology industry in Taiwan.

An examination of the impacts of firm size (control variable) on export performance showed that the path coefficients $(\beta)$ of competitive and financial performance, -0.009 and 0.059 , respectively, indicated they are not statistically significant. This implies that export performance is not significantly controlled by firm size. On the contrary, an examination of the impacts of export experience (control variable) on export performance showed that the path coefficients $(\beta)$ of competitive and financial performance, $150(p<0.05)$ and $0.184(p<0.015)$, respectively, indicated that both are statistically significant. This implies that export experience has a relative significant influence on export performance.

\section{Summary and Conclusion}

This study aimed to shed new light on the resource-based theory of dynamic capabilities from a marketing perspective. The theory of dynamic capabilities emphasizes timely response to environmental change and continuous renewal of resources for a sustainable competitive advantage, even in rapidly changing environments (Teece et al., 1997; Eisenhardt \& Martin, 2000). If not, companies may succumb to resource rigidity and lag behind in competitive advantage (Leonard-Barton, 1995). This concept of dynamic capabilities can be applied to all fields of value chain functions (Zahra et al., 2006), but is especially needed in marketing, where companies must respond sensitively to market environment changes. In this sense, dynamic marketing capabilities would be required more in overseas markets, where the market environment is completely distinct from domestic market. Therefore, to verify the effectiveness of dynamic marketing capabilities in overseas markets, this study analyzed the impacts of dynamic marketing capabilities on performance in the case of exporting.

Based upon the previous studies (Teece, 2007, 2018; Kwon, 2013) that conducted the operationalization of dynamic capabilities, this study categorized dynamic marketing capabilities as: 1) abilities to respond to market changes, namely "market responding capabilities"; and 2) abilities to integrate, form, and reconfigure marketing resources, namely "marketing resource rebuilding capabilities". Marketing responding capabilities are in line with the outside-in capabilities of a company that copes with market changes; on the other hand, marketing resource rebuilding capabilities are related to inside-out capabilities that focus on managing in-house company resources as stated by Day (1994).

As a result of empirically analyzing 180 export companies in Korea, the study found that market responding capabilities have significant positive impacts on competitive performance such as enhancement of corporate and brand awareness, reinforcement of price and quality competitiveness, and improvement of 
relationships with clients, but not on financial performance such as sales revenue and profit. On the other hand, marketing resource rebuilding capabilities had significant positive impacts on both competitive and financial performance. This result implies that market responding capabilities would be necessary to enhance competitive advantage. However, this market responding capabilities should be accompanied by the goodness of fit of resources aligning with market changes in order to secure financial performance. In summary, these results imply that it is not possible to achieve the desired financial performance without renewing or rebuilding resources, even if market responding capabilities are implemented, especially in exporting. However, previous studies emphasized only one dimension of dynamic marketing capabilities such as either market responding capabilities (Griffith et al., 2006; Fang \& Zou, 2009) or resource rebuilding capabilities (Wu, 2010; Kwon, 2010).

This study has academic significance in that it advanced the concept of dynamic marketing capabilities by applying the concept of dynamic capabilities to marketing. Moreover, it has strong policy implications in that it verified the effectiveness of dynamic marketing capabilities in the overseas market, where the market environment is completely different. However, there is a need for continuous discussions and research around the conceptualization and operationalization of dynamic marketing capabilities. Even though this research specifically studied the concept of dynamic marketing capabilities by applying it to overseas marketing, it will be interesting to conduct future research applying the concept of dynamic capabilities to other fields of value chain activities such as R \& D and logistics. In that sense, this study would be expected to provide guidelines for future research on the concept and operationalization of dynamic capabilities in not only marketing field but also other fields of value chain activities.

\section{Conflicts of Interest}

The author declares no conflicts of interest regarding the publication of this paper.

\section{References}

Abosag, I., \& Brennan, D. R. (2017). Understanding Marketing Innovativeness in Asia: A Research Agenda. Asian Business \& Management, 16, 212-225. https://doi.org/10.1057/s41291-017-0027-1

Andersson, S., Gabrieisson, J., \& Wictor, I. (2004). International Activities in Small Firms: Examining Factors Influencing the Internationalization and Export Growth of Small Firms. Canadian Journal of Administrative Science, 21, 22-34. https://doi.org/10.1111/j.1936-4490.2004.tb00320.x

Andersson, U., Forsgren, M., \& Holm, U. (2001). Subsidiary Embeddedness and Competence Development in MNCs: A Multi-Level Analysis. Organization Studies, 22, 1013-1034. https://doi.org/10.1177\%2F0170840601226005

Barney, J. B. (1991). Firm Resources and Sustained Competitive Advantage. Journal of Management, 17, 99-120. https://doi.org/10.1177\%2F014920639101700108 
Bortoluzzi, G., Chiarvesio, M., Di Maria, E., \& Tabacco, R. (2014). Exporters Moving Toward Emerging Markets: A Resource-Based Approach. International Marketing Review, 31, 506-525. https://doi.org/10.1108/IMR-12-2013-0280

Bruni, S. S., \& Verona, G. (2009). Dynamic Marketing Capabilities in Science-based Firms: An Exploratory Investigation of the Pharmaceutical Industry. British Journal of Management, 20, S101-S117. https://doi.org/10.1111/j.1467-8551.2008.00615.x

Cadogan, J. W., Diamantopoulos, A., \& Siguaw, J. A. (2002). Export Market-Oriented Activities: Antecedents and Performance Consequences. Journal of International Business Studies, 33, 615-626. https://doi.org/10.1057/palgrave.jibs.8491036

Carlsson, J., Nordegren, A., \& Sjöholm, F. (2005). International Experience and the Performance of Scandinavian Firms in China. International Business Review, 14, 21-40. https://doi.org/10.1016/j.ibusrev.2004.10.003

Chang, S.-J., Witteloostuijn, A., \& Eden, L. (2010). From the Editors: Common Method Variance in International Business Research. Journal of International Business Studies, 41, 178-184. https://doi.org/10.1057/jibs.2009.88

Collis, S., \& Montgomery, C. A. (1995). Competing on Resources. Harvard Business Review, 73, 118-128.

Day, G. S. (1994). The Capabilities of Market-Driven Organizations. Journal of Marketing, 58, 37-51. https://doi.org/10.1177\%2F002224299405800404

Deeds, D. A., Decaroles, D., \& Coombs, J. (2000). Dynamic Capabilities and New Product Development in High Technology Ventures: An Empirical Analysis of New Biotechnology Firms. Journal of Business Venturing, 15, 211-229. https://doi.org/10.1016/S0883-9026(98)00013-5

Diamantopoulos, A., Ring, A., Schlegelmilch, B. B., \& Doberer E. (2014). Drivers of Export Segmentation Effectiveness and Their Impact on Export Performance. Journal of International Marketing, 22, 39-61. https://doi.org/10.1509\%2Fjim.13.0075

Eisenhardt, K. M., \& Martin, J. A. (2000). Dynamic Capabilities: What Are They? Strategic Management Journal, 21, 1105-1121.

https://doi.org/10.1002/1097-0266(200010/11)21:10/11\%3C1105::AID-SMJ133\%3E3.0. CO;2-E

Fang, E., \& Zou, S. (2009). Antecedents and Consequences of Marketing Dynamic Capabilities in International Joint Ventures. Journal of International Business Studies, 40, 742-761. https://doi.org/10.1057/jibs.2008.96

Fornell, C., \& Larcker, D. F. (1981). Evaluating Structural Equation Models with Unobservable Variables and Measurement Error. Journal of Marketing Research, 18, 39-50. https://doi.org/10.1177\%2F002224378101800104

Grant, R. M. (1991). The Resource-Based Theory of Competitive Advantage: Implications for Strategy Formulation? California Management Review, 33, 114-135. https://doi.org/10.2307\%2F41166664

Griffith, A. A., Nobe, A. M., \& Chen, Q. (2006). The Performance Implications of Entrepreneurial Proclivity: A Dynamic Capabilities Approach. Journal of Retailing, 82, 51-62. https://doi.org/10.1016/j.jretai.2005.11.007

Griffith, D. A., \& Zhao, Y. (2015). Contract Specificity, Contract Violation, and Relationship Performance in International Buyer-Supplier Relationships. Journal of International Marketing, 23, 22-40. https://doi.org/10.1509\%2Fjim.14.0138

Harman, H. H. (1967). Modern Factor Analysis. Chicago: University of Chicago Press.

He, X., Brouthers, K. D., \& Filatotchev, I. (2018). Market Orientation and Export Performance: The Moderation of Channel and Institutional Distance. International Market- 
ing Review, 35, 258-279. https://doi.org/10.1108/IMR-09-2015-0194

Helfat, C. E. (1997). Know-How and Asset Complementary and Dynamic Capability Accumulation: The Case of R \& D. Strategic Management Journal, 18, 339-360. https://doi.org/10.1002/(SICI)1097-0266(199705)18:5\%3C339::AID-SMJ883\%3E3.0.C $\underline{0 ; 2-7}$

Hiroyuki, H. (1987). Mobilizing Invisible Assets. Harvard University Press.

Homburg, C., \& Pflesser, C. (2000). A Multiple-Layer Model of Market Oriented Organizational Culture: Measurement Issues and Performance Outcomes. Journal of Marketing Research, 37, 449-462. https://doi.org/10.1509\%2Fjmkr.37.4.449.18786

Hong, S. C., \& Chen, C. H. (1998). Market Orientation of Small and Medium-Sized Firms in Taiwan. Journal of Small Business Management, 36, 79-85.

Hong, S. J., \& Chaiy, S. I. (2008). Marketing Innovation: Its Definition, Dimensions, and Relationships with Firm Performance. Korea Management Review, 37, 133-164.

Hooley, G. J., Cox, A. J., Fahy, J., Beracs, J., Fonfara K., \& Snoj, B. (1999). Marketing Capabilities and Firm Performance: A Hierarchical Model. Journal of Market-Focused Management, 4, 259-278. https://doi.org/10.1023/A:1009879120167

Jaworski, B. J., \& Kohli, A. K. (1993). Market Orientation: Antecedents and Consequences. Journal of Marketing, 57, 53-70. https://doi.org/10.1177\%2F002224299305700304

Johnson, J. L., Lee, R. P., Saini, A., \& Grohmann, B. (2003). Market-Focused Strategic Flexibility: Conceptual Advances and an Integrative Model. Journal of the Academy Marketing Science, 31, Article No. 74. https://doi.org/10.1177/0092070302238603

Kohli, A. K., \& Jaworski, B. J. (1990). Market Orientation: The Construct, Research Propositions, and Managerial Implications. Journal of Marketing, 54, 1-18.

https://doi.org/10.1177\%2F002224299005400201

Kwon, Y. C. (2010). Dynamic Capabilities of Multinational Subsidiaries: Determinants and Performance. Korea Management Review, 39, 1151-1175.

Kwon, Y. C. (2013). Learning Orientation, Dynamic Capabilities and Performance in Korean High-Tech Ventures. Advances in Management, 6, 54-61.

Kwon, Y. C., \& Hu, M. Y. (2000). Market Orientation among Small Korean Exporters. International Business Review, 9, 61-75. https://doi.org/10.1016/S0969-5931(99)00029-3

Leonard-Barton, D. (1995). Wellsprings of Knowledge: Building and Sustaining Sources of Innovation. Harvard Business School Press.

Lisboa, A., Skarmeas, D., \& Lages, C. (2013). Export Market Exploitation and Exploration and Performance Linear, Moderated, Complementary and Non-Linear Effects. International Marketing Review, 30, 211-230. https://doi.org/10.1108/02651331311321972

McGrath, R. G. (2001). Exploratory Learning, Innovative Capacity, and Managerial Oversight. Academy of Management Journal, 44, 118-131.

Moore, M., \& Fairhurst, A. (2003). Marketing Capabilities and Firm Performance in Fashion Retailing. Journal of Fashion Marketing and Management, 7, 386-397. https://doi.org/10.1108/13612020310496976

Morgan, N. A., Vorhies, D. W., \& Mason, C. (2009). Market Orientation, Marketing Capabilities, and Firm Performance. Strategic Management Journal, 30, 909-920. https://doi.org/10.1002/smj.764

Narver, J. C., \& Slater, S. F. (1990). The Effect of a Market Orientation on Business Profitability. Journal of Marketing, 54, 20-35. 
https://doi.org/10.1177\%2F002224299005400403

Nunnally, J. C. (1978). Psychometric Theory. McGraw-Hill.

Oliveira, J. S., Cadogan, J. W., \& Souchon, A. (2012). Level of Analysis in Export Performance Research. International Marketing Review, 29, 114-127. https://doi.org/10.1108/02651331211201561

Pelham, A. M. (2000). Market Orientation and Other Potential Influences on Performance in Small and Medium-Sized Manufacturing Firms. Journal of Small Business Management, 8, 48-67.

Podsakoff, P. M., \& Organ, D. W. (1986). Self-Reports in Organizational Research: Problems and Prospects. Journal of Management, 12, 531-544. https://doi.org/10.1177\%2F014920638601200408

Porter, M. (1980). Competitive Strategy: Techniques for Analyzing Industries and Competitors. Free Press.

Ray, G., Barney, J. B., \& Muganna, W. A. (2004). Capabilities, Business Process, and Competitive Advantages: Choosing the Dependent Variable in Empirical Tests of the Resource-Based View. Strategic Management Journal, 25, 23-37. https://doi.org/10.1002/smj.366

Reid, S. D. (1982). The Impact of Size on Exporter Behavior of Small Firms. In M. R. Czinkota, \& G. Tesar (Eds.), Export Management: An International Context (pp. 17-38). Prager Publishers.

Rose, G. M., \& Shoham, A. (2002). Export Performance and Market Orientation: Establishing an Empirical Link. Journal of Business Research, 55, 217-225. https://doi.org/10.1016/S0148-2963(00)00139-9

Samiee, S., \& Walters, P. G. P. (1990). Influence of Firm Size on Export Planning and Performance. Journal of Business Research, 20, 235-248.

https://doi.org/10.1016/0148-2963(90)90015-6

Srivastava, R. K., Fashey, L., \& Christensen, H. K. (2001). The Resource-Based View and Marketing: The Role of Market-based Assets in Gaining Competitive Advantage. Journal of Management, 27, 777-802. https://doi.org/10.1177\%2F014920630102700610

Steenkamp, J. E. M., \& Van Trijp, H. C. M. (1991). The Use of LISREL in Validating Marketing Constructs. International Journal of Research in Marketing, 8, 283-299. https://doi.org/10.1016/0167-8116(91)90027-5

Teece, D. J. (2007). Explicating Dynamic Capabilities: The Nature and Microfoundations of (Sustainable) Enterprise Performance. Strategic Management Journal, 28, 1319-1350. https://doi.org/10.1002/smj.640

Teece, D. J. (2018). Business Models and Dynamic Capabilities. Long Range Planning, 51, 40-49. https://doi.org/10.1016/j.lrp.2017.06.007

Teece, D. J., Pisano, G., \& Shuen, A. (1997). Dynamic Capabilities and Strategic Management. Strategic Management Journal, 18, 509-533.

https://doi.org/10.1002/(SICI)1097-0266(199708)18:7\%3C509::AID-SMJ882\%3E3.0.C $\underline{\mathrm{O} ; 2-\mathrm{Z}}$

Vorhies, D. W., \& Morgan, N. A. (2005). Benchmarking Marketing Capabilities for Sustained Competitive Advantage. Journal of Marketing, 69, 80-94. https://doi.org/10.1509\%2Fjmkg.69.1.80.55505

Vorhies, D. W., Morgan, R. E., \& Autry, C. W. (2009). Product-Market Strategy and the Marketing Capabilities of the Firm: Impact on Market Effectiveness and Cash Flow Performance. Strategic Management Journal, 30, 1310-1334. 
https://doi.org/10.1002/smj.798

Wernerfelt, B. (1984). A Resource-Based View of the Firm. Strategic Management Journal, 5, 171-180. https://doi.org/10.1002/smj.4250050207

Wu, L. (2010). Applicability of Resource-Based and Dynamic-Capability View under Environment Volatility. Journal of Business Research, 63, 27-31.

https://doi.org/10.1016/j.jbusres.2009.01.007

Zahra, A. A., Sapienza, H. J., \& Davidson, P. (2006). Entrepreneurship and Dynamic Capabilities: A Review, Model and Research Agenda. Journal of Management Studies, 43, 917-955. https://doi.org/10.1111/j.1467-6486.2006.00616.x

Zhan, W., \& Luo, Y. (2008). Performance Implications of Capability Exploitation and Upgrading in International Joint Ventures. Management International Review, 48, 227-253. https://doi.org/10.1007/s11575-008-0013-0 